\title{
Bitlis Eren Üniversitesi Sağlık Hizmetleri Meslek Yüksekokulu Öğrencilerinde Depresyon Prevalansı ve ilişkili Faktörler
}

The Depression Prevalance and Related Factors in Students of

Bitlis Eren University Vocational School of Health Services

Fatma Söylemez', Ali Özer²

'Bitlis Eren Üniversitesi, Sağlık Hizmetleri Meslek Yüksekokulu, Bitlis

2 İnönü Üniversitesi Tıp Fakültesi, Halk Sağlığı AD, Malatya

Yazıșma Adresi / Correspondence:

Fatma Söylemez

Bitlis Eren Üniversitesi, Sağlık Hizmetleri Meslek Yüksekokulu, Bitlis

T: $+904342220000 \quad$ E-mail: fsoylemez@beu.edu.tr

Geliş Tarihi / Received : 31.05.2018 Kabul Tarihi / Accepted : 07.08.2018

Öz

Amaç Bu çalışmanın amacı; Bitlis Eren Üniversitesi Sağlık Hizmetleri Meslek Yüksek Okulu’nda öğrenim gören öğrencilerde depresyon sılığı ve depresyonla ilișkili faktörlerin araștrirlmasııdr. ( Sakarya Tip Dergisi, 2018, 8(3):551-561)

Gereç ve Bu çalıșma tanımlayıcı tipte kesitsel bir arastırmadır. Sosyodemografik özellikler, depresyonu etkileyebilecek faktörler ve Beck Depresyon

Yöntem Ölçeğinden oluşan anket formu Bitlis Eren Üniversitesi Sağlık Hizmetleri Meslek Yüksek Okulu’nda okuyan toplam 744 öğrenciden ulaşılan 682 'sine (\%92) araştırmacılar tarafından gözlem altında uygulanmıştır. İstatistiksel analizlerde; ki kare testi kullanılmış, satır yüzdeleri ele alınmış ve $p<0.05$ değeri anlamlı olarak kabul edilmiștir.

Bulgular Calıșma grubunun yas ortalaması 19.9+2.0 olup, \%77.7'si kadındır. Calışma grubunda Beck Depresyon Puanı 17 ve üstünde olanların oranı $\% 42.1^{\prime}$ dir. Sınıf ve cinsiyete göre Beck Depresyon Puanları arasında anlamlı fark yoktur ( $\left.p>0.05\right)$. Beck Depresyon Puanı 17 ve üstünde olan öğrencilerin oranı; sağık düzeyini kötü olarak değerlendiren öğrencilerde, sigara içenlerde, barınma sorunu olduğunu ifade edenlerde, düzensiz beslendiğini ifade edenlerde, bölümüne isteyerek gelmeyenlerde, okul başarı durumunu başarısız olarak değerlendirenlerde karşıt gruptakilere göre anlamlı oranda daha yüksektir $(p<0.05)$

Sonuç Üniversite öğrencilerinde yüksek depresyon oranları tespit edilmiștir. Depresyonu etkileyen; barınma, beslenme, okul başarısı, sağık düzeyi gibi değişkenlerin olumlu hale getirilmesinde; okul ve aile işbirliği ile sunulan etkili sağlık, sosyal ve psikolojik hizmetlerin geliştirilmesi önerilir.

Anahtar Depresyon; Üniversite; Öğrenciler

Kelimeler

Bu çalıșma , IMESET'17 Bitlis Konferansı'nda (International Conference on Multidisciplinary, Engineering, Science, Education and Technology, 27-29 Ekim 2017) sözel bildiri olarak sunulmuştur.

\footnotetext{
Abstract

Objective The aim of this study is to investigate prevalence of depression in students studying at Bitlis Eren University Vocational School of Health Services and the factors affecting depression. ( Sakarya Med J, 2018, 8(3):551-561).

Materials and This is a descriptive cross-sectional study. A questionnaire involving socio-demographic characteristics, factors affecting depression, and Methods Beck Depression inventory was applied under observation by the researchers to $682(92 \%)$ reached among totally 744 students studying at Bitlis Eren University Vocational School of Health Services.

In the statistical analyses; chi-square test was used, percentage of lines was evaluated, and $p<0.05$ was accepted as statistically significant.

Results Average age of study group was $19.9 \pm 2.0$ and $77.7 \%$ were women. The rate of those having Beck Depression Score of 17 and higher in study group was $42.1 \%$. There was no significant difference between Beck Depression Scores in terms of year and gender $(p>0.05)$. The rate of students having Beck Depression Score 17 and above was significantly higher than the contrast groups in students assessing their health status as bad, in smokers, in those stating to have accommodation problem, in those stated to have irregular eating habit, in those not studying at their department willingly, in those evaluating academic standing as unsuccessful $(p<0.05)$.
} 
Sakarya TIp Dergisi

2018;8(3):551-561

SÖYLEMEZ ve Ark

\section{Giriş}

Depresyon prevalansı yüksek, küresel hastalık yüküne katkısı olan bir halk sağlığı sorunudur. Dünyada her yaştan yaklaşık 300 milyon kişinin depresyondan etkilendiği tahmin edilmektedir. Depresyon sıradan ruh hali dalgalanmaları ve günlük yaşamda zorluklara karşı kısa duygusal tepkilerden farklıdır. ${ }^{1}$

Depresyon üzüntü, ilgi ve zevk kaybı, suçluluk ya da düşük öz-değer, bozulmuş uyku veya iştah, yorgunluk hissi ve düşük konsantrasyon ile karakterize yaygın bir ruhsal bozukluktur. Depresyon ve fiziksel sağlık arasında karşılıklı bir ilişki vardır. Örneğin depresyon kardiyovasküler sorunlara yol açı̆ı̆ı gibi kardiyovasküler hastalıklar depresyona neden olabilir. ${ }^{2}$

Depresyon intihara neden olan en önemli etmenlerden biridir ve dünyada yılda yaklaşık 1 milyon kişi intihar nedeniyle hayatını kaybetmektedir. ${ }^{3}$

Dünya Sağılı Örgütü’nün “Küresel Hastalık Yükü 2010” çalışmasında depresyon dünya çapında küresel hastalık yüküne yol açan hastalıklar arasında dördüncü sırada olmakla beraber 2020 yıllarında iskemik kalp hastalıklarından sonra 2. sırada yer alacağı belirtilmektedir. ${ }^{4}$

Küresel Hastalık Yükü 2010 çalışmasına göre; iş ve sosyal kayıplar, oluşturduğu olumsuzluklar nedeniyle tüm hastalıklar arasında yeti kaybı yönünden incelendiğinde; ruhsal bozuklukların \%40,5'inden depresyon tek başına sorumludur. Depresif hastalıklarda yeti kaybı açısından yaş grupları arasında en yüksek oran 10-29 yaş arası ergenlerde ve orta yaşlı yetişkinlerde görülmektedir. ${ }^{4,5}$

Depresyonun yaşam boyu görülme sıklığının \%1,5 ile \%19 arasında olduğu bildirilmektedir. ${ }^{6}$

2014 Türkiye Sağlık Raporuna göre; nöropsikiyatrik hastalıklar erkeklerde hastalık yükünün \%12'sini, kadınlarda \%15'ini oluşturmaktadır. Türkiye'de ulusal düzeyde tüm hastalıklar arasında yeti kaybı yönünden incelendiğinde hastalık yüküne neden olan ilk 10 hastalığın 15-59 yaş grubunda bakıldığında unipolar depresif hastalıklar kadınlarda \% \%,8 ile birinci sırada toplamda \%7,0 ile ikinci sırada, erkeklerde \%4,5 ile dördüncü sırada saptanmıştır. "Türkiye Ruh Sağlığı Profili” çerçevesinde 18 yaş ve üstündeki 7479 kişinin son 12 aydaki tanılar değerlendirildiğinde araştırmaya katılanların \%17,2'sine en az bir ruhsal hastalık tanısı konmuş ve majör depresyonun en yaygın görülen hastalıklardan olduğu belirtilmiştir. ${ }^{7}$

2011 yllında KISA (Brief Patient Health Questionnaire) anketi kullanılarak yapılan Türkiye Kronik Hastalıklar ve Risk Faktörlerinin Sıklığı Çalışmasında; 15 yaş üstü toplumda depresif bozukluk sıklığı $\% 9$ ve 15 - 24 yaş grubunda $\% 5,1^{\prime}$ dir. $^{8}$

Ergenlik dönemi, sosyal ve fiziksel değişimlerin, kişinin yetişkinliğe geçişini ve bir birey olmasını sağlayan, büyük değişim ve gelişimlerin yaşandığı; duygusal davranışsal, cinsel, ekonomik, akademik ve toplumsal çatışmaların olduğu bir dönemdir. ${ }^{9,10}$ Ergenlerin depresyon açısından yüksek riskli bireyler olduğu, özellikle 13-18 yaş gençler arasında depresyonun arttığı ve hastalık sıklğını önlemek için ergenliğin önemli bir dönem olduğunu bildirilmektedir. ${ }^{5,11}$ 
Üniversite gençliği yaş dönemleri içerisinde değerlendirildiğinde; ergenlik döneminden yetişkinlik dönemine geçiş arasında yer alan bir süreçtir. Bu dönemde aileden ayrılma, yeni çevre ve arkadaş edinme, yalnız kalma korkusu, ekonomik güçlükler, yurt hayatına alışma, gelecek kaygıları gibi sorunlar gözlenmektedir. Üniversite öğrencileri arasında yapılan araştırmalarda bu grup için en önemli ruhsal bozukluğun depresyon olduğu belirtilmektedir. ${ }^{12,13,14}$

Bu çalışmanın amacı; Bitlis Eren Üniversitesi Sağlık Hizmetleri Meslek Yüksek Okulu’nda öğrenim gören üniversite öğrencilerinde depresyon sıklığı ve depresyonla ilişkili faktörlerin araştııılmasıdır.

\section{Gereç ve Yöntemler}

Bu araştırma Bitlis Eren Üniversitesi Sağılı Hizmetleri Meslek Yüksekokulu 2015-2016 eğitim öğretim ylı bahar yarıyılında öğrenim gören öğrenciler üzerinde yapılmış tanımlayıcı tipte kesitsel bir araştırmadır.

Sosyodemografik özellikler ve depresyonu etkileyebilecek faktörler literatür araştırması ile tespit edilerek 23 sorudan oluşan bir sosyodemografik veri formu oluşturulmuş ve Beck Depresyon Ölçeğindeki 21 soru eklenerek toplam 44 soru içeren anket formu kullanıımıştır. Araştırmanın evrenini 2015-2016 bahar yarıylında Bitlis Eren Üniversitesi Sağlık Hizmetleri Meslek Yüksek Okulu’nda örgün öğrenim gören toplam 744 öğrenci oluşturmaktadır. Evrenin tümü araştırmaya alınmış 62 öğrenci; okula devam etmeme, kayit dondurma, anket formunu reddetme gibi nedenlerden araştırmaya katılmamıştır. Anket formu; ulaşılan 682 öğrenciye araştırmacılar tarafından gözlem altında uygulanmıştır. Araştırmaya katııım oranı \%92'dir.

Bitlis Eren Üniversitesi Etik Kurulu 23.03.2016 tarihli ve 2016/5.1 sayılı kararı ile onay alınmıştır. Araştırma öncesi ön test yapılmıştır.

Beck Depresyon Ölçeği (BDÖ); Beck Depresyon Ölçeği Beck ve arkadaşları tarafından adölesan ve erişkinlerde depresyonun davranışsal bulgularını ölçmek amacıyla 1961 ylında geliştirilmiş̧ir. ${ }^{15,16}$ İstatistiksel Analiz: Verilerin değerlendirilmesi Statistical Package for the Social Sciences (SPSS) 16.0 paket programı kullanılarak yapılmışır. İstatistiksel analizlerde; ki kare testi kullanılmış, satır yüzdeleri ele alınmış ve $p<0.05$ değeri anlamlı olarak kabul edilmiştir.

Değerlendirmelerde sorulan soruya cevap vermeyenler dahil edilmemiş olup sadece söz konusu soruyu cevaplayanlar değerlendirilmiştir.

\section{Bulgular}

Çalışma grubunun yaş ortalaması 19.9+2.0 olup, \%77.7’si kadındır. Öğrencilerin sosyo demografik özellikleri Tablo.1'de sunulmuştur.

Tablo 2'de görüldüğü gibi çalışma grubunda Beck Depresyon Ölçeği (BDÖ) puanları 17 ve üstünde olanların oranı \%42.1'dir. Çalışma grubunda Beck Depresyon Ölçeği (BDÖ) puanları 17 ve üstünde olan öğrencilerin oranı; sağlık düzeyini kötü olarak değerlendiren öğrencilerde (\%75.6) iyi olarak değerlendirenlerden (\%30.6), sigara içenlerde (\%60.6) içmeyenlerden (\% 37.8), barınma sorunu olduğunu ifade edenlerde (\%64.3) barınma sorunu olmadığını ifade edenlerden (\% 40.1), düzensiz beslendiğini ifade edenlerde (\%51.7) düzenli beslenenlerden (\% 26.7), bölümüne isteyerek gelmeyenlerde (\%54.3) isteyerek gelen öğrencilerden $(\% 36,2)$, okul başarı durumunu başarısız ola-
Sakarya Tip Dergisi

$2018 ; 8(3): 551-561$

SÖYLEMEZ ve Ark. Bittlis Eren Üniv. Sä̆lik Hizm. MYo öğrencilerinde Depresyon Prevalansi ve iliş̧kli Fakkoorler 
rak değerlendirenlerde (\%64.9) başarılı olarak değerlendirenlerden(\%34,5) anlamlı oranda daha yüksektir $(p<0.05)$.

Tablo 1: Öğrencilerin sosyo demografik özellikleri

\begin{tabular}{|c|c|c|}
\hline & n & $\%$ \\
\hline \multicolumn{3}{|l|}{ Sinif } \\
\hline 1 & 369 & 54,1 \\
\hline 2 & 313 & 45,9 \\
\hline \multicolumn{3}{|l|}{ Yaş } \\
\hline 18 ve altı & 101 & 14,8 \\
\hline 19 & 207 & 30,4 \\
\hline 20 & 204 & 29,9 \\
\hline 21 ve üstü & 170 & 24,9 \\
\hline \multicolumn{3}{|l|}{ Anne meslek } \\
\hline Ev hanımı & 668 & 97,9 \\
\hline İşçi & 8 & 1,2 \\
\hline Emekli & 2 & 0,3 \\
\hline Serbest meslek & 4 & 0,6 \\
\hline \multicolumn{3}{|l|}{ Baba meslek } \\
\hline İşsiz & 93 & 13,6 \\
\hline İşçi & 128 & 18,8 \\
\hline Memur & 105 & 15,4 \\
\hline Emekli & 137 & 20,1 \\
\hline Serbest meslek & 219 & 32,1 \\
\hline \multicolumn{3}{|c|}{ Üniversiteye gelmeden önce yaşadığı yer } \\
\hline il merkezi & 275 & 40,3 \\
\hline illçe & 251 & 36,8 \\
\hline Köy & 156 & 22,9 \\
\hline \multicolumn{3}{|l|}{ Aile yapısı } \\
\hline Çekirdek aile & 438 & 64,2 \\
\hline Geniş aile & 220 & 32,3 \\
\hline Parçalanmış aile & 24 & 3,5 \\
\hline \multicolumn{3}{|l|}{ Sosyal güvence } \\
\hline Var & 420 & 61,6 \\
\hline Yok & 262 & 38,4 \\
\hline \multicolumn{3}{|l|}{ Kardeş sayısı } \\
\hline $0-2$ & 39 & 5,7 \\
\hline $3-5$ & 265 & 38,9 \\
\hline $6-8$ & 258 & 37,8 \\
\hline 9 ve üstü & 120 & 17,6 \\
\hline \multicolumn{3}{|l|}{ Aile geliri } \\
\hline 650 ve altı & 159 & 23,3 \\
\hline $651-1300$ & 323 & 47,4 \\
\hline 1301-2499 & 122 & 17,9 \\
\hline 2500 ve üstü & 78 & 11,4 \\
\hline
\end{tabular}


Tablo 2: Öğrencilerin yaș, sağlığını değerlendirme, sigara kullanma, barınma sorunu, beslenme durumu, bölüme isteyerek gelme ve okul başarı durumlarına göre BDö puanlarının karşılaştırılması

\begin{tabular}{|c|c|c|c|c|c|c|}
\hline & & \multicolumn{2}{|c|}{17 altı } & \multicolumn{2}{|c|}{17 ve üstü } & \multirow{2}{*}{$X^{2}, p, s d$} \\
\hline & & $n$ & \%(satır) & $n$ & $\%$ (satır) & \\
\hline \multirow{4}{*}{ Yaş } & 18 ve altı & 48 & $47,5^{*}$ & 53 & 52,5 & \multirow{4}{*}{$\begin{array}{l}X^{2}:=10,256 \\
p<0,017 \\
s d=3\end{array}$} \\
\hline & 19 & 134 & 64,7 & 73 & 35,3 & \\
\hline & 20 & 110 & 53,9 & 94 & 46,1 & \\
\hline & 21 ve üstü & 103 & 60,6 & 67 & 39,4 & \\
\hline \multirow{3}{*}{ Sağlığını değerlendirme } & iyi & 225 & $69,4^{*}$ & 99 & 30,6 & \multirow{3}{*}{$\begin{array}{l}x^{2}=44,858 \\
p<0,001 \\
s d=2\end{array}$} \\
\hline & orta & 159 & $50,8^{*}$ & 154 & 49,2 & \\
\hline & kötü & 11 & 24,4 & 34 & 75,6 & \\
\hline \multirow{2}{*}{ Sigara kullanma } & evet & 50 & 39,4 & 77 & 60,6 & \multirow{2}{*}{$\begin{array}{l}X^{2}=22,028 \\
p<0,001\end{array}$} \\
\hline & hayır & 345 & 62,2 & 210 & 37,8 & \\
\hline \multirow{2}{*}{ Barınma sorunu } & var & 20 & 35,7 & 36 & 64,3 & \multirow{2}{*}{$\begin{array}{l}X^{2}=12,243 \\
p<0,001\end{array}$} \\
\hline & yok & 375 & 59,9 & 251 & 40,1 & \\
\hline \multirow{2}{*}{ Beslenme durumu } & düzenli & 192 & 73,3 & 70 & 26,7 & \multirow{2}{*}{$\begin{array}{l}x^{2}=41,207 \\
p<0,001\end{array}$} \\
\hline & düzensiz & 203 & 48,3 & 217 & 51,7 & \\
\hline \multirow{2}{*}{ Bölüme isteyerek gelme } & evet & 294 & 63,8 & 167 & 36,2 & \multirow{2}{*}{$\begin{array}{l}X^{2}=20,020 \\
p<0,001\end{array}$} \\
\hline & hayır & 101 & 45,7 & 120 & 54,3 & \\
\hline \multirow{3}{*}{ Okul başarı durumu } & başarısız & 26 & $35,1^{*}$ & 48 & 64,9 & \multirow{3}{*}{$\begin{array}{l}X^{2}=19,497 \\
p<0,001 \\
s d=2\end{array}$} \\
\hline & $\begin{array}{l}\text { orta dere- } \\
\text { cede başarlı }\end{array}$ & 274 & 59,2 & 189 & 40,8 & \\
\hline & & 95 & 65,5 & 50 & 34,5 & \\
\hline *Farkı olușturan gruplar & \multicolumn{6}{|c|}{ BDÖ: Beck Depresyon Ölçeği } \\
\hline
\end{tabular}

Tablo 3'te görüldüğü gibi çalışma grubunda Beck Depresyon Ölçeği (BDÖ) puanları 17 ve üstünde olan öğrencilerin oranı; 2.sınıfta öğrenim gören öğrencilerde $(\% 43,1) 1$. sınıf öğrencilerden (\% $41,2)$, kadınlarda (\% 43,6) erkeklerden( $\% 36,8)$, üniversiteye gelmeden önce köyde yaşayanlarda (\% 44,9) il merkezinde yaşayanlardan (\% 40,4), parçalanmış ailede yaşayanlarda $(\% 62,5)$ çekirdek ailede yaşayanlardan $(\% 40,2)$, sosyal güvencesi olmayanlarda( $(\% 46,6)$ sosyal güvencesi olanlardan $(\% 39,3)$, aile geliri 650 tl ve altı olanlarda $(\% 45,3) 2500$ tl ve üstü olanlardan(\%32,1), anne öğrenim durumu lise ve üstü olanlarda $(\% 44,4)$ ortaokul olanlardan(\%41,7), baba öğrenim durumu üniversite ve üstü olanlarda $(\% 45,6)$ lise ve üstü olanlardan $(\% 41,1)$, kardeş sayısı 6-8 olanlarda(\%45,3) 9 ve üstü olanlardan $(34,2)$ yüksektir.

Çalışma grubunda sınıf, cinsiyet, üniversiteye gelmeden önce yaşadığı yer, aile yapısı, sosyal güvence, aile geliri, anne öğrenim durumu, baba öğrenim durumu ve kardeş sayısına göre Beck Depresyon Ölçeği (BDÖ) puanları arasında anlamlı fark yoktur ( $p>0.05)$.
Sakarya Tıp Dergisi

2018;8(3):551-561

SÖYLEMEZ ve Ark. Bitlis Eren Üniv. Aağ lik Hizm. MYo öğrencilerinde Depresyon Prevalansı ve ilişkili Faktörler 
Tablo 3: Öğrencilerin sınıf, cinsiyet, üniversiteye gelmeden önce yaşadığı yer, aile yapısı, sosyal güvence, aile geliri, anne öğrenim durumu, baba öğrenim durumu ve kardeş sayısına göre BDÖ puanlarının karşılaştırılması

\begin{tabular}{|c|c|c|c|c|c|c|}
\hline \multirow{2}{*}{ Değişkenler } & & \multicolumn{2}{|c|}{17 altı } & \multicolumn{2}{|c|}{17 ve üstü } & \multirow{2}{*}{$X^{2}, p, s d$} \\
\hline & & n & $\%$ (satır) & n & $\%$ (satır) & \\
\hline \multirow{2}{*}{ Sinıf } & 1 & 217 & 58,8 & 152 & 41,2 & \multirow{2}{*}{$\begin{array}{l}X 2=0.261 \\
p<0,609 \\
s d=1\end{array}$} \\
\hline & 2 & 178 & 56,9 & 135 & 43,1 & \\
\hline \multirow{2}{*}{ Cinsiyet } & kadın & 299 & 56,4 & 231 & 43,6 & \multirow{2}{*}{$\begin{array}{l}X 2=2,203 \\
p<0,138\end{array}$} \\
\hline & erkek & 96 & 63,2 & 56 & 36,8 & \\
\hline \multirow{3}{*}{$\begin{array}{l}\text { Üniversiteye gelmeden } \\
\text { önce yaşadığı yer }\end{array}$} & il merkezi & 164 & 59,6 & 111 & 40,4 & \multirow{3}{*}{$\begin{array}{l}x 2=0,834 \\
p<0,659 \\
s d=2\end{array}$} \\
\hline & ilçe & 145 & 57,8 & 106 & 42,2 & \\
\hline & köy & 86 & 55,1 & 70 & 44,9 & \\
\hline \multirow{3}{*}{ Aile yapısı } & çekirdek aile & 262 & 59,8 & 176 & 40,2 & \multirow{3}{*}{$\begin{array}{l}X 2=4,972 \\
p<0,083 \\
s d=2\end{array}$} \\
\hline & parçalanmış aile & 9 & 37,5 & 15 & 62,5 & \\
\hline & geniş aile & 124 & 56,4 & 96 & 43,6 & \\
\hline \multirow{2}{*}{ Sosyal güvence } & var & 255 & 60,7 & 165 & 39,3 & \multirow{2}{*}{$\begin{array}{l}x 2=3,508 \\
p<0,061\end{array}$} \\
\hline & yok & 140 & 53,4 & 122 & 46,6 & \\
\hline \multirow{4}{*}{ Aile geliri } & 650- ve altı & 87 & 54,7 & 72 & 45,3 & \multirow{4}{*}{$\begin{array}{l}X 2=4,012 \\
p<0,260 \\
s d=3\end{array}$} \\
\hline & $651-1299$ & 184 & 57,0 & 139 & 43,0 & \\
\hline & $1300-2499$ & 71 & 58,2 & 51 & 41,8 & \\
\hline & 2500 ve üstü & 53 & 67,9 & 25 & 32,1 & \\
\hline \multirow{4}{*}{ Anne öğrenim durumu } & okur yazar değil & 202 & 58,0 & 146 & 42,0 & \multirow{4}{*}{$\begin{array}{l}x 2=0,068 \\
p<0,995 \\
s d=3\end{array}$} \\
\hline & ilkokul & 143 & 57,9 & 104 & 42,1 & \\
\hline & ortaokul & 35 & 58,3 & 25 & 41,7 & \\
\hline & lise ve üstü & 15 & 55,6 & 12 & 44,4 & \\
\hline \multirow{5}{*}{ Baba öğrenim durumu } & okur yazar değil & 43 & 57,3 & 32 & 42,7 & \multirow{5}{*}{$\begin{array}{l}x 2=0,426 \\
p<0,980 \\
s d=4\end{array}$} \\
\hline & ilkokul & 158 & 58,3 & 113 & 41,7 & \\
\hline & ortaokul & 84 & 58,3 & 60 & 41,7 & \\
\hline & lise & 73 & 58,9 & 51 & 41,1 & \\
\hline & üniversite ve üstü & 37 & 54,4 & 31 & 45,6 & \\
\hline \multirow{4}{*}{ Kardeş sayısı } & $0-2$ & 24 & 61,5 & 15 & 38,5 & \multirow{4}{*}{$\begin{array}{l}x 2=4,520 \\
p<0,211 \\
s d=3\end{array}$} \\
\hline & $3-5$ & 151 & 57,0 & 114 & 43 & \\
\hline & $6-8$ & 141 & 54,7 & 117 & 45,3 & \\
\hline & & 79 & 65,8 & 41 & 34,2 & \\
\hline
\end{tabular}

\section{Tartışma}

Ruh sağlğı üniversite öğrencileri arasında epidemiyolojik verilere ihtiyaç duyulan, önemli ve büyüyen bir halk sağlığı sorunudur. ${ }^{17}$

Çalışmamızda BDÖ kesme noktasına göre depresyon görülme sıklığı \% 42.1 'dir. Literatürde yer alan çalışmalara göre; Givens ve arkadaşlarının 2002 tarihli California'da BDÖ ölçeği kullanarak yaptıkları çalışmada 1. ve 2. sınıf tıp öğrencilerinde depresyon prevalansı \%24.0, Dahlin ve arkadaşlarının Isveç'in Stockholm kentinde tıp fakültesi öğrencilerinde yaptıkları 2005 tarihli çalışmada depresif belirti prevalansı \%12.9, İnam ve arkadaşlarının 2003 tarihli Pakistan'ın Karachi Tıp Fakültesinde yaptıkları çalışmada depresyon ve anksiyete prevalansı \%60.0, Tomoda ve arkadaşlarının 2000 tarihli Japonya'nın Tokyo kentinde üniversite öğrencileriyle yaptıkları çalışmada depresyon prevalansı 
\%20.7, Eisenberg ve arkadaşlarının 2007 tarihinde Amerika'da Michigan Üniversitesi'nde üniversite öğrencilerinde yaptıkları çalışmada lisans öğrencilerinde depresyon yaygınlığı \%15.6, Avenevoli ve arkadaşlarının 2016 tarihli Amerika'da adölesanlarda yaptığı çalışmada 18 yaş adölesanların depresyon prevalansı $\% 8.1^{\prime}$ dir. ${ }^{5,17-21}$

Ülkemizde yapılan çalışma sonuçlarına göre; Deveci ve arkadaşlarının 2013 tarihli Kilis'te Sağık Yüksekokulu öğrencileriyle yaptıkları çalışmada; BDÖ puanı 17 ve üstünde olan öğrenci sıklığı \%18.3'tür. Temel ve arkadaşlarının yaptığı 2007 tarihli Gaziantep'te Sağlık Yüksekokulu öğrencileriyle yaptığı çalışmada; BDÖ puanı 17 ve üstü olan öğrenciler \%33.3, Günay ve arkadaşlarının 2018 tarihli Erciyes Üniversitesi öğrencilerine yaptıkları çalışmada%26.4, Özdel ve arkadaşlarının 2002 tarihli Pamukkale Üniversitesi'nde yaptıkları çalışmada \%26.2, Dinç Hür ve arkadaşlarının 2014 tarihli Karabük Üniversitesi Sağlık Yüksekokulu’nda yaptıkları çalısmada \%\%25.0, Ulaş ve arkadaşlarının Gaziantep Hasan Kalyoncu Üniversitesi öğrencilerine yaptıkları çalışmada \%38.3, Alparslan ve arkadaşlarının Sağlık Yüksekokulu ve Teknik Eğitim Fakültesinde yaptıkları çalışmada;\%38.3, Kaya ve arkadaşlarının 2007 tarihli İnönü Üniversitesinde yaptıkları çalışmada Sağlık Yüksekokulu öğrencilerinde \%31.8 ve Tıp Fakültesi öğrencilerinde \%21.9 olarak bildirilmiştir. ${ }^{10,12,22-25}$

Çalışmalara bakıldığında; yurt dışı çalışmalarda depresyon prevalansı \%8.1 ile \%60.0 arasında yurt içi çalışmalarda \%18.3 ile \%38.3’tür. Pakistan'da yapılan çalışmada depresyon prevalansı çalışmamızdan oldukça yüksek oranda olup, Amerika, Japonya, İsveç’te yapılan çalışmalarda depresyon prevalansı çalışmamızdan daha düşüktür. Bunun nedeni ülkelerin gelişmişlik düzeylerinin sosyal ve ekonomik duruma etkisi olabilir. Çalışmamı sonuçları incelen yurt içi çalışmalarından yüksektir. Yurt içi çalışmalardaki farklılık üniversiteler ve bölgeler arası sosyal, demografik etkenlerle açıklanabilir.

Çalışma grubunda 18 yaş ve altında depresyon görülme sıklığı (\%52.5) 19,20 ve 21 yaş ve üstü gruplara oranla (\%35.3, \%46.1, \%39.4) anlamlı derecede yüksek bulunmuştur (Tablo 2). Literatürde bu konuyla ilgili çalışmalar incelendiğinde genç yaş grubunda yaş düştükçe depresyonun arttı̆̆ını gösteren çalışmalar ve yaş artıkça öğrencilerin son sınıfa yaklaştıkça yaşam kaygılarının arttı̆ı̆nı, adölesanlarda yüksek yaş grubunun depresyon varlığı risk faktörü olduğunu bildiren çalışmalarda mevcuttur. ${ }^{10,12,22,23,26}$ Erişkinlere oranla adölesanlarda depresyon yaygınlığının daha fazla olduğunu bildiren çalışmalar mevcuttur. ${ }^{10,26}$ Kilis 7 Aralık Üniversitesi Sağlık Yüksekokulu'nda 2013 yilında yapılan çalışmada 17-19 yaş grubunda BDÖ puan ortalaması daha üst yaşlara oranla yüksek bulunmuş olup bizim çalışmamıza benzer olarak yaş grupları arasında istatistiksel olarak anlamlı bir fark bulunamamıştır. ${ }^{12}$ Pamukkale Üniversitesi öğrencileri arasında 2002 ylında yapılan çalışmada araştırmamıza benzer şekilde yaş grupları arasında istatistiksel olarak anlamlı bir fark bulunamamıştır. ${ }^{13}$ Erciyes Üniversitesi öğrencilerinde 2018 yılında yapılan araştırmada bizim çalışmamızın aksine 17-19 yaş grubu BDÖ puanları 20 yaş ve üzeri öğrencilere oranla istatistiksel olarak anlamlı derecede düşük bulunmuştur. ${ }^{23}$ İnönü Üniversitesi Sağlık Yüksekokulu ve Tıp Fakültesi öğrencileri arasında yapılan bir çalışmada yaş artışı ile depresyon varlı̆̆ı arasında istatistiksel olarak anlamlı bir ilişki olduğunu bildirilmektedir. ${ }^{10}$ Çalışmamızda düşük yaş grubunda depresyon varlığının diğer yaş gruplarına oranla yüksek olmasının sebebi; Bitlis Eren Üniversitesi öğrencilerinin büyük bir çoğunluğunun Doğu ve Güney Doğu Anadolu kökenli olması ve ilk defa ailelerinden ayrilıp gelen öğrencilerde stres düzeylerinin yüksek olması, Bitlis ilinin sosyal faaliyet imkanları, çalışma döne-
Sakarya Tıp Dergisi

2018;8(3):551-561

SÖYLEMEZ ve Ark. Bitlis Eren Üniv. Sağllk Hizm. MYO Öğrencilerinde Depresyon Prevalansı ve ilişkili Faktörler 
Sakarya TIp Dergisi 2018;8(3):551-561

SÖYLEMEZ ve Ark Bitlis Eren Üniv. Sağık Hizm. MYO Öğrencilerinde Depresyon Prevalansı ve ilişkili Faktörler mindeki terör olayları, coğrafi olumsuzluklar ve iklim açısından negatif bir algı oluşturması olabilir. Çalışma grubunda depresyon görülme sıklığı sağlık düzeyini kötü olarak değerlendiren öğrencilerde (\%75.6) iyi olarak değerlendirenlerden (\%30.6) anlamlı derecede yüksektir (Tablo 2). Kilis 7 Aralık Üniversitesi Sağık Yüksekokulu'nda ve Erciyes Üniversitesi öğrencilerinde yapılan çalışmalarda sağılık düzeyi ile depresyon varlığı arasında istatistiksel açıdan anlamlı bir fark bulunmuştur. ${ }^{12,23}$ İnönü Üniversitesi öğrencilerinde yapılan çalışmada; bedensel bir hastalığı bulunanların depresyon puanları yüksek olmasına rağmen istatistiksel açıdan bir fark olmadığı ancak ruhsal bir hastalı̆ı bulunma ile depresyon puanları ile anlamlı bir ilişki olduğu bildirilmektedir.10 Gaziantep Sağlık Yüksekokulu öğrencilerinde yapılan çalışmada fiziksel ve ruhsal sağlık durumu ile depresyon arasında anlamlı bir ilişki bulunmuştur. ${ }^{22}$ Karabük Üniversitesi Sağılık Yüksekokulu öğrencileri arasında 2014 tarihli ve Hasan Kalyoncu Üniversitesi öğrencilerinde 2015 yllında yapılan çalışmalarda kronik hastalık varlığı ile depresyon varlığı arasında anlamlı bir ilişki bulunmuştur. ${ }^{14,24}$ Bu bilgiler ışığında sağık durumunu kötü olarak değerlendirmenin depresyonu arttırdığı, fiziksel sağlık durumunun ruhsal sağlı̆̆ da etkilediği söylenebilir.

Çalışma grubunda depresyon görülme sıklığı sigara içenlerde (\%60.6) içmeyenlerden (\% 37.8) anlamlı derecede yüksektir (Tablo 2). Kilis 7 Aralık Üniversitesi Sağlık Yüksekokulu öğrencilerini kapsayan çalışmada sigara kullanma durumu ile depresyon puanları arasında ilişki bulunmamıştır. ${ }^{12}$ Sigara bağımlılarında depresyon geçirme olasılığı sigara bağımlısı olmayanlara göre iki kat fazla olduğu bildirilmektedir. ${ }^{27}$

Çalışma grubunda depresyon görülme sıklığı barınma sorunu olduğunu ifade edenlerde (\%64.3) barınma sorunu olmadığını ifade edenlerden (\% 40.1) anlamlı derecede yüksektir (Tablo 2). Kilis 7 Aralık Üniversitesi Sağıık Yüksekokulu öğrencileri arasında yapılan çalışmada barınma sorunu ile depresyon varlı̆ı arasında istatistiksel bir ilişki bulunmuştur. ${ }^{12}$ Pamukkale Üniversitesi öğrencileri arasında yapılan çalışmada barınma sorunu ile depresyon arasında ilişki olmadığı belirtilmiştir. ${ }^{13}$ Üniversitenin yeni olması ve öğrenci kapasitesinin sürekli artmasına yurtlar cevap veremeyebilir. Barınma temel ihtiyaçlardandır ve bu ihtiyacını karşılamakta sorun yaşayan öğrencilerde ruhsal belirtiler ortaya çıkabilir.

Çalışma grubunda depresyon görülme sıklığı düzensiz beslendiğini ifade edenlerde (\%51.7) düzenli beslenenlerden (\% 26.7) anlamlı derecede yüksektir (Tablo 2). Kilis 7 Aralık Üniversitesi Sağlık Yüksekokulu öğrencilerini kapsayan çalışmada beslenme durumu ile depresyon varlı̆̆ı arasında istatistiksel olarak anlamlı bir ilişki vardır. ${ }^{12}$ Pamukkale Üniversitesi öğrencileri arasında yapılan çaış̧mada beslenme sorunu ile depresyon arasında anlamlı bir ilişki bulunamamıştır. ${ }^{13}$

Çalışma grubunda depresyon görülme sıklığı bölümüne isteyerek gelmeyenlerde (\%54.3) isteyerek gelen öğrencilerden $(\% 36,2)$ anlamlı derecede yüksektir (Tablo 2). Kilis 7 Aralık Üniversitesi Sağlık Yüksekokulu, Karabük Üniversitesi Sağılık Yüksekokulu ve Hasan Kalyoncu Üniversitesi öğrencilerinde yapılan çalışmalarda bölümüne isteyerek gelip gelmeme ile depresyon varlığı arasında istatistiksel olarak anlamlı ilişki saptanmıştır. ${ }^{12,14,24}$ Gaziantep Sağlık Yüksekokulu öğrencilerinde yapılan çalışmada mesleğini isteyerek seçme ile depresyon arasında bir ilişki bildirilmemiştir. Aynı çalışmada okul hayatından memnun olma ile depresyon arasında anlamlı bir ilişki olduğu bildirilmektedir. ${ }^{22}$ Öğrencilerin okudukları bölümler büyük ölçüde gelecekte yapacakları mesleklere yönlendirmekte- 
dir. İstemediği bir bölümde öğrenim görmek öğrencilerin ruh sağlığını olumsuz etkilemiş olabilir. Çalışma grubunda depresyon görülme sıklığı okul başarı durumunu başarısız olarak değerlendirenlerde (\%64.9) başarıı olarak değerlendirenlerden $(\% 34,5)$ anlamlı derecede yüksektir (Tablo 2). Hasan Kalyoncu Üniversitesi öğrencilerinde ve Pamukkale Üniversitesi öğrencilerinde yapılan çalışmalarda öğrencilerin başarı durumu ile depresyon arasında istatistiksel olarak anlamlı bir ilişki bulunmuştur. Çalışmalarda depresyonun başarıyı azalttı̆̆ı, başarının azalmasının da depresyonu ortaya çıkarabileceği bildirilmektedir. ${ }^{13,24}$

Çalışma grubunda Beck Depresyon Ölçeği (BDÖ) puanları 17 ve üstünde olan öğrencilerin oranı; 2.sınıfta öğrenim gören öğrencilerde 1. sınıf öğrencilerden, kadınlarda erkeklerden, üniversiteye gelmeden önce köyde yaşayanlarda il merkezinde yaşayanlardan, parçalanmış ailede yaşayanlarda çekirdek ailede yaşayanlardan, sosyal güvencesi olmayanlarda sosyal güvencesi olanlardan, aile geliri 650 tl ve altı olanlarda 2500 tl ve üstü olanlardan, anne öğrenim durumu lise ve üstü olanlarda ortaokul olanlardan, baba öğrenim durumu üniversite ve üstü olanlarda lise ve üstü olanlardan, kardeş sayısı 6-8 olanlarda 9 ve üstü olanlardan daha yüksek olmasına rağmen sınıf, cinsiyet, üniversiteye gelmeden önce yaşadığı yer, aile yapısı, sosyal güvence, aile geliri, anne öğrenim durumu, baba öğrenim durumu ve kardeş sayısına göre Beck Depresyon Puanları arasında istatistiksel olarak anlamlı bir fark yoktur (Tablo 3). Kilis 7 Aralık Üniversitesi Sağık Yüksekokulu öğrencileri arasında yapılan çalışma anne öğrenim durumu ve kardeş sayısı ile depresyon arasında istatistiksel olarak anlamlı bir ilişki olduğunu bildirmektedir. Çalışmada cinsiyet, sınıf, okula gelmeden yaşadığı yer, sosyal güvence durumu, aile geliri, baba öğrenim durumu, aile yapısı ile depresyon arasında bir ilişki saptanmamıştır. ${ }^{12}$ İnam ve arkadaşlarının 2003 yilında Pakistan'ın Karachi kenti Tıp Fakültesinde yaptıkları çalışmada sınıf ile depresyon arasında istatistiksel olarak anlamlı ilişki olduğu, aylık gelir ve kardeş sayısının depresyonu etkilemediği bildirilmiştir. ${ }^{20}$ Tomoda ve arkadaşlarının 2000 yılında Japonya'nın Tokyo kentinde üniversite öğrencileriyle yaptıkları çalışmada cinsiyet ile depresyon arasında istatistiksel olarak anlamlı bir fark bulunamamıştır. ${ }^{21}$ Erciyes Üniversitesi öğrencilerinde yapılan çalışmaya göre; cinsiyet, ekonomik durum ile depresyon arasında bu çalışmanın tersine anlamlı bir ilişki saptanmıştır. ${ }^{23}$ İnönü Üniversitesi Sağlık Yüksekokulu ve Tıp Fakültesi öğrencileri arasında yapılan çalışmada cinsiyet, anne öğrenim durumu, baba öğrenim durumu ve aile geliri ile depresyon arasında istatistiksel olarak anlamlı ilişki bulunmamaktadır. Bu çalışmada aile tipi ile depresyon arasında bir ilişki bulunmuş, parçalanmış aileden gelen öğrencilerde depresyonun yaygın olduğu bildirilmiştir. ${ }^{10}$ Pamukkale Üniversitesi öğrencilerinde yapılan araştırmada sınıf, cinsiyet, anne öğrenim durumu, baba öğrenim durumu, kardeş sayısı, ailenin yaşadığı yer, ailenin aylık gelir durumu ile depresyon arasında istatistiksel olarak anlamlı bir ilişki bulunamamıştır. ${ }^{13}$ Gaziantep Sağlık Yüksekokulu öğrencileri arasında yapılan çalışmada sınıf, kardeş sayısı ile depresyon arasında anlamlı ilişki belirlenmiştir. ${ }^{22}$ Hasan Kalyoncu Üniversitesi öğrencileri arasında yapılan araştırmada ekonomik durumla depresyon arasında bir ilişki olduğu bildirilmiştir. Aynı çalışmada cinsiyet ve aile yapısı ile depresyon arasında anlamlı bir ilişki bulunmadığı bildirilmektedir. ${ }^{24} \mathrm{Al}$ parslan ve arkadaşlarının Sağlık Yüksekokulu ve Teknik Eğitim Fakültesi öğrencileri arasında yapılan çalışmasında cinsiyet ile depresyon arasında anlamlı bir ilişki olmadığı, sınıf ile depresyon arasında anlamlı bir ilişki olduğu ve 2. sınıfların 3. sınıftan daha depresif olduğu bildirilmektedir. ${ }^{25}$

Majör depresyonun kız ve erkeklerde görülme oranının 2/1 olduğu bildirilmesine rağmen çalışmamızda cinsiyetler arası fark bulunamamıştır. ${ }^{26}$ Literatürde kadınlarda depresyon erkeklerden daha sık görülmektedir ve biyolojik yatkınlğın yanında kadınlarda eğitim seviyesi ve sosyoekonomik
Sakarya Tip Dergisi

2018;8(3):551-561

SÖYLEMEZ ve Ank Bittis Eren Üniv. Sağılı Hizm. MYo öğrencilerinde Depresyon Prevalansı ve ilişkili Faktörler 
Sakarya TIp Dergisi 2018;8(3):551-561

düzeyin düşük olması bunun için bir risk faktörü olarak tespit edilmiştir. ${ }^{28}$ Bu çalışmada kadınlarda depresyonun erkeklere göre daha yüksek olmaması eğitimli bir grupla çalışmış olmamızdan kaynaklanıyor olabilir. Eğitim olanakları eşit olduğunda kadınlar depresyona biyolojik olarak olarak daha yatkın olsalar bile sosyal koşulların düzenlenmesi ile bunu dengeliyor olabilirler. Bu anlamda kadınlara ve erkeklere başta eğitim olmak üzere sosyal koşullarda fırsat eşitliğinin sağlanması depresyonu önleme açısından yararlı olacaktır.

Sonuç olarak üniversite öğrencilerinin beşte ikisinde depresyon tespit edilmiştir. Depresyon literatür çalışmalarına oranla oldukça yüksektir. Gelecekte sağlık hizmeti verecek bu grupta ruh sağlığı ile ilgili yaklaşımlarda bulunulmalı ve ortaya çıkaran, etkileyen faktörlere ait elde ettiğimiz bulgular yol gösterici olmalıdır. Depresyonu etkileyen; barınma, beslenme, okul başarısı, sağlık düzeyi gibi değişkenlerin olumlu hale getirilmesinde; üniversite bünyesinde sunulacak etkili sağlık, sosyal ve psikolojik hizmetler önemli yer tutmaktadır.

Çalışmanın kısıtıılıkları: Çalışmamız sadece Bitlis Eren Üniversitenin Sağlık Hizmetleri Meslek Yüksekokulu öğrencileri arasında, küçük bir örneklem grubuyla yapıldığından aynı alanda öğrenim gören öğrencilerin tümüne genellenemez. Ancak bulgularımız üniversite öğrencilerine yönelik yapılacak çalışmalarda olumlu katkı sağlaması açısından önemlidir. 
1. http://www.who.int/mediacentre/factsheets/fs369/en/ Erișim Tarihi 30.04.2018

2. http://www.who.int/mental_health/management/depression/en/ Erişim Tarihi:02.05.2018

3. http://www.who.int/mental_health/management/depression/who_paper_depression_wfmh_2012.pdf?ua=1 Erişim Tarihi:02.05.2018

4. Whiteford HA, Degenhardt L, Rehm J, Baxter AJ, Ferrari AJ, Erskine HE, Charlson F), Norman RE, Flaxman AD, Johns N, Burstein R, Murray C), Vos T. Global burden of disease attributable to mental and substance use disorders: findings from the Global Burden of Disease Study 2010. Lancet, 2013 Nov 9;382(9904):1575-1586

5. Avenevoli S, Swendsen J, He JP, Burstein, M, Merikangas K. Major Depression in the National Comorbidity Survey- Adolescent Supplement Prevalence, Correlates, and Treatment, J Am Acad Child Adolesc Psychiatry. 2015 January; 54(1):37-44

6. Olchanski N, Mclnnis Myers M, Halseth M, Cyr PL, Bockstedt L, Goss TF, Howland RH. The economic burden of treatment-resistant depression. Clinical therapeutics, 2013;35(4):512-522.

7. 2014 Türkiye Sağlik Raporu http://halksagligiokulu.org/anasayfa/ components/com_booklibrary/ebooks/TSR2014T.PDF Erişim Tarihi: 03.05.2018

8. Türkiye Kronik Hastalıklar ve Risk Faktörleri Sıklığı Calıșması, Sağlık Bakanlı̆̆ Yayın No: 909, Ankara, 2013 http://sbu.saglik.gov.tr/Ekutuphane/ kitaplar/khrfat.pdf Erişim Tarihi: 04.05.2018

9. Taşkın EO, Gürlek Yüksel E, Özmen E. Üniversite birinci sınıf öğrencilerinde ayrılma bireyleşme özellikleri ve depresyon ilișkisi. Anadolu Psikiyatri Dergisi 2009;10:174-180.

10. Kaya M, Genç M, Kaya B, Pehlivan E.Tıp Fakültesi ve Sağlık Yüksekokulu Öğrencilerinde Depresif Belirti Yaygınlı̆ı, Stresle Başaçıkma Tarzları ve Etkileyen Faktörler. Türk Psikiyatri Dergisi, 2007;18(2):137-146.

11. Twenge, J. M., \& Nolen-Hoeksema, S. (2002). Age, gender, race, socio economic status, and birth cohort difference on the children's depression inventory: A meta-analysis. Journal of Abnormal Psychology, 111(4), 578-588.

12. Deveci SE, Ulutaşdemir N, Açık Y. Bir Sağlık Yüksekokulunda Öğrencilerde Depresyon Belirtilerinin Görülme Sıkığı ve Etkileyen Faktörler. Fırat Tıp Derg/Firat Med J 2013; 18(2): 98-102

13. Özdel L, Bostancı M, Özdel o, Nalan KO. Üniversite öğrencilerinde dep resif belirtiler ve sosyodemografik özelliklerle ilișkisi. Anadolu Psikiyatr Dergisi, 2002;3:155-161.

14. Dinç Hür S, Andsoy II, Oksay Şahin A, Kayhan M, Eren S, Zünbül S Zünbül N, Akgün H, İnanmaz N. Karabük Üniversitesi Sağllk Yüksekokulu Öğrencilerinde Depresif Belirtiler. Journal Of Psychiatric Nursing, 2014;5(2):72-76
15. Kilınç S, Torun F. Türkiye'de Klinikte Kullanılan Depresyon Değerlendirme Ölçekleri. Dirim Tıp Gazetesi, 2011;86(1):39-47.

16. Hisli N. Beck Depresyon Envanteri'nin üniversite öğrencileri için geçerliği, güvenirliği. Psikoloji Dergisi, 1989;7(23):3-13.

17. Eisenberg D, Gollust SE, Golberstein E, Hefner IL. Prevalence and correlates of depression, anxiety, and suicidality among university students. American Journal of Orthopsychiatry, 2007;77(4),534-542.

18.18. Givens JL, Tjia J. Depressed medical students' use of mental health services and barriers to use. Academic Medicine, 2002; Sep;77(9):918-921.

19. Dahlin M, Joneborg N, Runason B. Stress and depression among medical students: a cross-sectional study. Medical Education, 2005;39:594-604.

20. İnam SNB, Saqib A, Alam E. Prevalence of anxiety and depression among medical students of private university. J Pak Med Assoc. 2003 Feb;53(2):44-47.

21. Tomoda A, Mori K, Kımura M, Takahashı T, Kitamura T. One-year prevalence and incidence of depression among first-year university students in Japan: a preliminary study. Psychiatry Clin Neurosci. 2000 Oct:54(5):583-8.

22. Temel E, Bahar A, Çuhadar D. Öğrenci Hemşirelerin Stresle Başetme Tarzları ve Depresyon Düzeylerinin Belirlenmesi. Fırat Sağlık Hizmetleri Dergisi, 2007;2(5):107-118

23. Günay O, Öztürk A, Arslantaş EE, Sevinç N. Düșünen Adam, The Journal of Psychiatry and Neurological Sciences ,2018;31:79-88.

24. Ulaş B, Tatıbadem B, Nazik F, Sönmez M, Uncu F. Üniversite Öğrencilerinde Depresyon Sıklığı. Celal Bayar Üniversitesi Sağlık Bilimleri Enstitüsü Dergisi, 2015;2(3):71-75.

25. Alparslan N, Yaşar S, Dereli E, Turan N. Sağlık Yüksekokulu ve Teknik Eğitim Fakültesi Öğrencilerinde Görülen Depresif Belirtiler ve Bunu Etkileyen Faktörlerin İncelenmesi. Hemșirelikte Araștırma Geliștirme Dergisi, 2008;2:48-57.

26. Öztürk MO, Uluşahin NA. Ruh Sağlı̆ı ve Bozuklukları. Nobel Tıp Yayınevleri, Ankara, 2015;602-603.

27. Sigara ve Ruh Sağığı. Sağlık Bakanlığı Yayın No: 731. Ankara,2008. https://havanikoru.org.tr/dosya/dokumanlar/sagligimiza_etkileri/Sigara_ve_Ruh_Sagligi.pdf Erișim Tarihi: 05.05.2018.

28. Bursalioglu FS, Aydin N, Yazici E, Yazici AB. The correlation between psychiatric disorders and women's lives. Journal of clinical and diagnostic research, JCDR, 2013;7(4): 695 .
Sakarya Tıp Dergisi 2018;8(3):551-561

SÖYLEMEZ ve Ark. Bitlis Eren Üniv. Sağllk Hizm. MYO Öğrencilerinde Depresyon Prevalansı ve ilişkili Faktörler 